\title{
DEVELOPING WEAR MODEL OF CONSTRUCTION MATERIALS IN ABRASIVE SOIL PULP EMPLOYING DISCRIMINANT ANALYSIS
}

\author{
Jerzy Napiorkowski, Pawel Mikolajczak, Stanislaw Legutko, Jolanta B. Krolczyk
}

Original scientific paper

This paper presents a method of selecting the chemical composition and structure of the surface layer of construction materials to suit the property of the abrasive soil pulp being processed. The experiment was conducted in a laboratory, by the "rotating mass" method. The mathematical model developed for the experiment enables simulation of the wear changes of the construction materials used in soil, depending on changing of chemical composition and structure of the construction material and soil humidity. The results produced in the experiment have shown that the wear intensity in gravel soil may be acceptable for both materials containing less than $20 \% \mathrm{C}+\mathrm{Cr}$ (used in soil with humidity of more than $12 \%$ ) and in tribological unfavourable conditions (soil humidity below $6 \%$ ), if the $\mathrm{C}+\mathrm{Cr}$ content in the construction material exceeds $25 \%$.

Keywords: abrasive soil pulp; discriminant analysis; microstructure; wear

Razvoj modela trošenja konstrukcijskih materijala u abrazivnoj zemljanoj masi uporabom diskriminantne analize

Izvorni znanstveni članak

U radu se opisuje metoda odabira kemijskog sastava i strukture površinskog sloja konstrukcijskih materijala koji odgovaraju svojstvima abrazivne zemljane mase koja se obrađuje. Eksperiment je proveden u laboratoriju metodom "rotirajuće mase". Matematičkim modelom razvijenim za eksperiment omogućena je simulacija promjena $\mathrm{u}$ trošenju konstrukcijskih materijala korištenih u zemlji ovisno o promjeni kemijskog sastava i strukture konstrukcijskog materijala i vlažnosti zemlje. Rezultati pokazuju da intenzitet trošenja u šljunčanom tlu može biti prihvatljiv za materijale koji sadrže manje od $20 \% \mathrm{C}+\mathrm{Cr}$ (upotrebljene u tlu s vlažnošću višom od 12 \%) kao i u tribološki nepovoljnim uvjetima (vlažnost tla ispod 6 \%), ako je sadržaj C+Cr u konstrukcijskom materijalu viši od $25 \%$.

Ključne riječi: abrazivna zemljana masa; diskriminantna analiza; mikrostruktura; trošenje

\section{Introduction}

The intensity of wear of a working part which is in contact with soil is affected by the soil properties, the characteristics of the working part and the mechanics of the interactions [1, 2]. Wear of a part in abrasive soil pulp is usually classified as abrasive wear and is defined as the process of damaging the surface layer by friction as a result of the slicing, grooving, scratching and shearing action of soil particles with different aggregation sizes [3 $-6]$. Abrasive soil pulp is a compound natural object in which constant decomposition, synthesis and displacement processes take place, both of mineral and organic substances. The process of wear of working parts in abrasive soil pulp is a natural one. The process control range depends on the knowledge of the wear processes and their controllability. The greatest role in the wear process is attributed to physicochemical properties of the abrasive soil pulp, which include granulometric composition, consistency, humidity and acidity [7].

Resistance to wear in soil is strongly dependent on hardness, plasticity, microstructure and its instability and anisotropy of the crystalline surface layer. These properties are best shaped by the proper selection of the chemical composition, including the size, shape and fixing of carbides [8]. One of the methods of shaping the properties of surface layers (which helps to suit them to individual conditions of use) is the use of pad-welded layers. The selection criterion is chosen based on two directions, mainly to achieve the suitable hardness and creating a specific phase composition of the heterogeneous structure of padding weld $[9 \div 12]$. The best anti-wear properties in abrasive soil pulp have been observed in materials obtained from $\mathrm{Fe}$ and $\mathrm{Cr}$ with an addition of transitional metals $\mathrm{V}, \mathrm{W}, \mathrm{Mn}, \mathrm{Nb}$ and amphoteric B. The compound structure is a result of the internal elements of the material, which include three hard phases of carbides $\left(\mathrm{Mo}_{2} \mathrm{C}, \mathrm{VC}, \mathrm{TiC},(\mathrm{Fe}, \mathrm{Cr})_{3} \mathrm{C}, \mathrm{W}_{2} \mathrm{C}\right)$ precipitated during the material solidification [4]. Using $\mathrm{Fe}-\mathrm{Cr}-\mathrm{Fe}$ alloys as a reference point results from the fact that the alloys in which chromium is the main component are the most commonly used and are regarded as the most cost-effective. Evaluation of the properties of padding welds has been made in many studies of the macro- and microstructure and their hardness depending on the chemical composition of the material. There have been no reports containing an analysis of the utility features of padding welds with respect to their choice for the soil type, its properties and the tribological system of wear. Therefore, attempts have been made in order to develop mathematical models to describe the relationship between the properties of soil and chemical composition of layers. Friction and wear of materials is a wide subject of interest in industrial facility $[13,14]$.

The aim of this study was to develop a method of selection of properties of construction materials with respect to wear in abrasive soil pulp, employing discriminant analysis.

\section{Study methods}

A laboratory experiment was carried out on a "rotating bowl" wear machine (Fig.1). The sample had the form of a cuboid with the dimensions of $30 \times 25 \times 10$ $\mathrm{mm}$, made of $38 \mathrm{GSA}$ steel, on which layers of various chemical compositions were placed by the padding technique.

The friction plane was fixed at the angle of $2 \div 3^{\circ}$ with respect to the surface being treated. Friction trials were made at the load of $53 \mathrm{kPa}$, friction speed of $2 \mathrm{~m} / \mathrm{s}$ and 
friction path of $10000 \mathrm{~m}$. After a friction trial along the path of $2 \mathrm{~km}$, a sample was weighed and the soil was replaced with new soil. Mass wear of samples was measured with laboratory scales weighing with an accuracy of $\pm 10^{-4} \mathrm{~g}$. Six samples of each type of the surface layer were examined, which resulted in the confidence coefficient of $\beta=0,95$, and in the maximum error of $q=10 \%$.

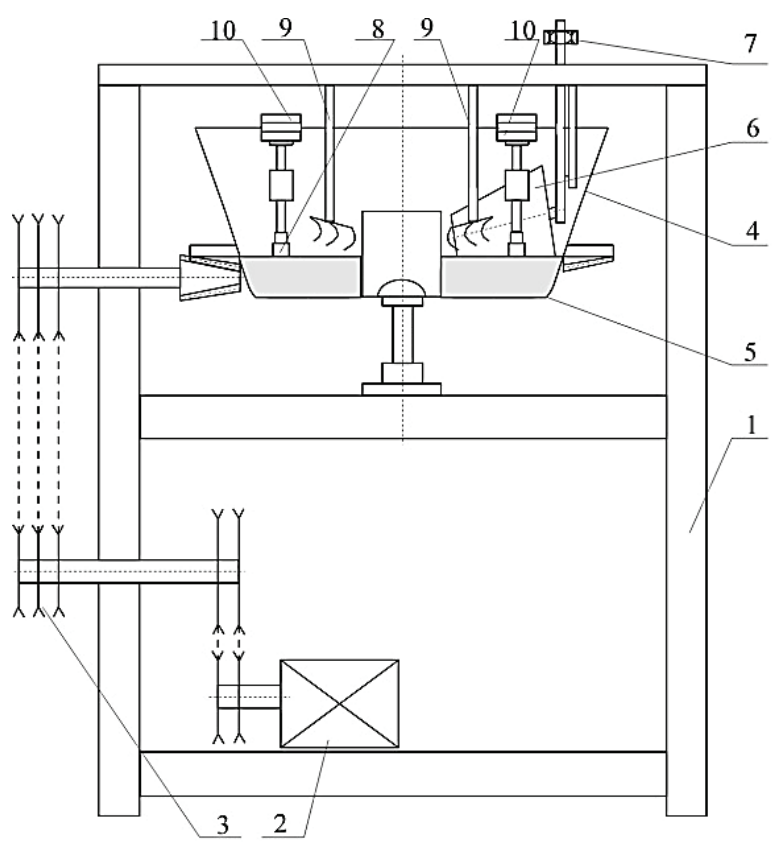

Figure 1 A stand for examination of wear in abrasive soil pulp: 1 - frame, 2 - motor, 3 - belt transmission, 4 - bowl, 5 - soil, 6 - pressing rollers, 7 - roller pressing, 8 - grip with sample, 9- scarifying fork, 10- sample weights

Natural soil was used as the abrasive pulp; its granulometric composition was determined by the Bouyoucos-Casagrande's areometric method as sandy gravel with the following composition: gravel $(>1 \mathrm{~mm})$ $56,6 \%$, sand $(0,1 \div 1,0 \mathrm{~mm}) 25,4 \%$, dust $(0,02 \div 0,1$ mm) $9,4 \%$ and silt $(0,02 \mathrm{~mm}) 8,6 \%$. The experiment was carried out for over $9 \%$ humidity for sandy soil and up to $15 \%$ humidity for clay soil, which soils are mostly treated in practice for that moist levels. The soil $\mathrm{pH}$, measured by the electromotory method, ranged from 6,42 $\div 7,07$.
The wear was determined by means of determination of weight wear from the following formula:

$Z_{w}=m_{w}-m_{i}$

$m_{w}$ - starting mass of sample before the friction trial $(\mathrm{g})$, $m_{i}$-sample mass after friction path has been covered $(\mathrm{g})$.

\section{Materials}

Materials put onto 38GSA steel (BN 85/0642-48) were used in the experiment; those were put on by the following methods:

a) arc surfacing by a covered electrode:

- EStelMn60 - series I;

- EN600B - series II;

- ENSW2Mo-B - series III;

- EStelMoNb60 - series IV.

b) arc surfacing by self-covered flux-cored wire:

- DPIS9 - series V.

c) plasma surfacing by metallic powders:

- $\quad$ PMFe61P - series VI;

- $\quad \mathrm{PMFeCr65 \textrm {P }}$ - series VII

The microscopic examination was carried out by a Neophot 52 microscope at magnifications ranging from 50 to 2000 times, using ordinary and inversion objectives. Layer observation was carried out on scanning microscopes: TESLA BS340 coupled with a micro analyser TESLA NL-2001A and STEREOSCAN 180 with a Link System microanalysis attachment.

Ground and polished samples were etched with the following reagents: chromic acid for electrolytic etching, $5 \%$ alcohol solution of $\mathrm{HNO}_{3}$ for 38GSA steel and for etching padding welds and the "Murakami" reagent for selective etching of carbides. The chemical composition was determined with the use of a "BAIRD'S SPECTROVAL", which acts on the principle of analytical atomic absorption with direct readout. Hardness was determined with a Vickers HMO10u hardness tester as per PN-EN ISO 6507-1:1999, at the probe load of $98 \mathrm{~N}$, during $10 \mathrm{~s}$ for all the measurements. The characteristics of the surface layer are presented in tables 1 and 2 . The samples were prepared using standard metallographic techniques [16] by grinding, polishing, and etching.

Table 1 Chemical composition of the padding welds

\begin{tabular}{|c|c|c|c|c|c|c|c|}
\hline \multirow{2}{*}{$\begin{array}{l}\text { Ingredients content } \\
(\%)\end{array}$} & \multicolumn{7}{|c|}{ RESEARCH SERIES } \\
\hline & $\mathrm{I}$ & II & III & IV & $\mathrm{V}$ & VI & VII \\
\hline $\mathrm{C}$ & 3,40 & 0,61 & 0,94 & 5,31 & 4,19 & 2,25 & 1,85 \\
\hline $\mathrm{Mn}$ & 4,32 & 0,73 & 1,63 & 1,28 & 1,43 & 1,19 & 0,62 \\
\hline $\mathrm{Si}$ & 1,68 & 0,98 & 1,06 & 1,46 & 0,38 & 2,21 & 0,86 \\
\hline $\mathrm{Cr}$ & 31,60 & 5,34 & 5,41 & 21,90 & 20,50 & 40,60 & 10,50 \\
\hline Mo & 0,04 & 0,01 & 6,83 & 7,66 & 0,11 & 0,03 & 0,02 \\
\hline $\mathrm{Ni}$ & 0,30 & 0,16 & 0,17 & 0,06 & 0,12 & 0,59 & 1,27 \\
\hline $\mathrm{Al}$ & 0,03 & 0,01 & 0,01 & 0,05 & 0,04 & 0,05 & 0,01 \\
\hline $\mathrm{Cu}$ & 0,09 & 0,06 & 0,12 & 0,09 & 0,08 & 0,40 & 4,00 \\
\hline $\mathrm{P}$ & 0,05 & 0,03 & 0,01 & 0,02 & 0,04 & 0,06 & 0,02 \\
\hline $\mathrm{S}$ & 0,01 & 0,02 & 0,05 & 0,02 & 0,01 & 0,02 & 0,02 \\
\hline B & 0,03 & - & - & - & - & 2,77 & 0,09 \\
\hline $\mathrm{W}$ & 0,05 & 0,04 & - & 2,00 & - & - & - \\
\hline $\mathrm{V}$ & - & - & - & 1,70 & 0,06 & - & 0,02 \\
\hline $\mathrm{Ti}$ & - & - & - & 0,03 & - & - & - \\
\hline $\mathrm{Nb}$ & - & - & - & 7,00 & - & - & - \\
\hline
\end{tabular}




\begin{tabular}{|c|c|c|c|}
\hline Series & Microstructure & Description of microstructure & $\begin{array}{c}\text { Hardness } \\
\text { HV10 } \\
\end{array}$ \\
\hline I & 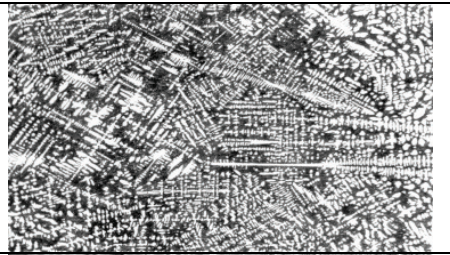 & $\begin{array}{l}\text { Varied structure on the thickness and length } \\
\text { Fusion zone: alloy ferrite with numerous carbides } \\
(\mathrm{Fe}, \mathrm{Cr})_{3} \mathrm{C} \text {. } \\
\text { Padding weld: primary carbides eutectic mixture }\left[\alpha+(\mathrm{Fe}, \mathrm{Cr})_{7} \mathrm{C}_{3}\right] \text {, } \\
\text { mainly with plate-like structure }+ \text { residual austenite. Mag. } 200 \times\end{array}$ & $620 \div 726$ \\
\hline II & & $\begin{array}{c}\text { Varied dendritic-grainy structure } \\
\text { Fusion zone: alloy ferrite } \\
\text { Padding weld: alloy ferrite }+ \text { eutectoid }\left(\alpha+\mathrm{Cr}_{7} \mathrm{C}_{3}\right)+\text { chromium } \\
\text { carbide. Mag. } 200 \times\end{array}$ & $624 \div 762$ \\
\hline III & & $\begin{array}{l}\text { Varied dendritic structure } \\
\text { Fusion zone: alloy ferrite with carbides located on grain borders } \\
\text { Padding weld: alloy ferrite with small molybdenum carbides on } \\
\text { grain borders and inside them. Mag. } 3000 \times\end{array}$ & $720 \div 762$ \\
\hline IV & & $\begin{array}{c}\text { Dendritic structure } \\
\text { Fusion zone: alloy ferrite } \\
\text { Padding weld: alloy ferrite with numerous carbides of the } \\
\mathrm{Mo}_{2} \mathrm{C}, \mathrm{VC}, \mathrm{TiC} \text { type. And with eutectics }\left[\alpha+(\mathrm{Fe}, \mathrm{Cr})_{7} \mathrm{C}_{3}\right] \\
\text { Mag. } 200 \times\end{array}$ & $707 \div 824$ \\
\hline V & 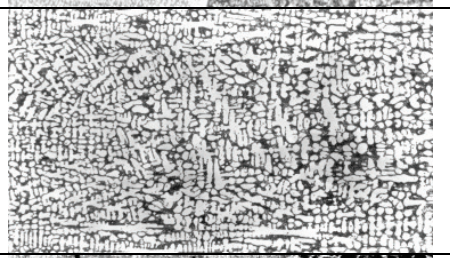 & $\begin{array}{c}\text { Dendritic structure } \\
\text { Fusion zone: alloy ferrite } \\
\text { Padding weld: alloy ferrite + eutectics }\left[\alpha+(\mathrm{Fe}, \mathrm{Cr})_{7} \mathrm{C}_{3}\right] \text { with a } \\
\text { plate-like structure. Mag. } 200 \times\end{array}$ & $606 \div 680$ \\
\hline VI & & $\begin{array}{c}\text { Fusion zone: alloy ferrite } \\
\text { Padding weld: primary carbides }(\mathrm{Fe}, \mathrm{Cr})_{7} \mathrm{C}_{3} \text { with a strip } \\
\text { structure, with an eutectic base }\left[\alpha+(\mathrm{Fe}, \mathrm{Cr})_{7} \mathrm{C}_{3}\right] \text { as well as } \\
\text { borides carbide-borides. Mag. } 50 \times\end{array}$ & $650 \div 862$ \\
\hline VII & 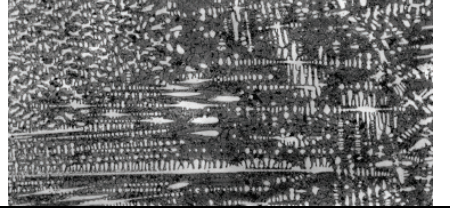 & $\begin{array}{l}\text { Fusion zone: alloy ferrite } \\
\text { Padding weld: alloy ferrite }+ \text { primary borides }(\mathrm{Fe}, \mathrm{Cr})_{7} \mathrm{C}_{3} \text { against } \\
\text { the background of compound eutectics }+ \text { intrusions of copper. } \\
\text { Mag. } 200 \times\end{array}$ & $790 \div 820$ \\
\hline
\end{tabular}

\section{$4 \quad$ A wear model employing discriminant analysis}

Discriminant analysis is a statistical technique which can examine differences between two or more groups by simultaneous analysis of several variables. The variables used to distinguish groups are called discriminant variables. In practical terms, discriminant analysis is a broad term, which refers to several related statistical procedures. In simple terms, the procedures can be classified as follows [16, 17]:

- Procedures which describe and interpret inter-group differences. The procedures explain: Is it possible to distinguish one group from another having a set of several variables? How well does variable discrimination help to distinguish between groups? Which groups discriminate the best?
- Procedures of case classification, i.e. establishing based on the attributes values - to which group a new case should be included. It is related to creating one or more functions which classify the cases under analysis into the appropriate groups.

An example of discriminant analysis was considered using laboratory data of the wear of 7 construction materials, characterised in table 1 and 2, for different values of humidity of abrasive gravel pulp, shown in Tab. 3. The aim of the analysis is to show the possibility of forecasting the course of wear in relation to: the content of $\mathrm{C}+\mathrm{Cr}, \mathrm{Mn}$, admixtures of other transitional and amphoteric elements $\operatorname{Re}(\mathrm{Mo}+\mathrm{B}+\mathrm{W}+\mathrm{V}+\mathrm{Ti}+\mathrm{Nb})$ and soil humidity $\mathrm{H}$. Table 4 shows the criteria of interpretation of the values of wear in gravel soil [4]. 
Table 3 Juxtaposition of four independent variables $(\mathrm{C}+\mathrm{Cr}, \mathrm{Mn}, \mathrm{Re}, \mathrm{H})$ and the discriminant variable

\begin{tabular}{|c|c|c|c|c|c|}
\hline $\begin{array}{l}\text { Experiment } \\
\text { variant }\end{array}$ & $\begin{array}{c}\mathrm{C}+\mathrm{CR}(\%) \\
\text { Independent } \\
\text { variable } 1\end{array}$ & $\begin{array}{c}\text { Mn }(\%) \\
\text { Independent } \\
\text { variable } 2\end{array}$ & $\begin{array}{c}\mathrm{Re}(\%)(\mathrm{Mo}+\mathrm{B}+\mathrm{W}+\mathrm{V}+\mathrm{Ti}+\mathrm{Nb}) \\
\text { Independent variable } 3\end{array}$ & $\begin{array}{c}\mathrm{H}(\%) \\
\text { Independent } \\
\text { variable } 4\end{array}$ & $\begin{array}{c}\text { Value of wear } \\
\text { Discriminant variable }\end{array}$ \\
\hline V1 & 35,00 & 4,32 & 0,12 & 6 & Acceptable \\
\hline $\mathrm{V} 2$ & 35,00 & 4,32 & 0,12 & 13 & Satisfactory \\
\hline V3 & 5,95 & 0,73 & 0,05 & 5 & Unacceptable \\
\hline V4 & 5,95 & 0,73 & 0,05 & 12 & Acceptable \\
\hline V5 & 6,35 & 1,63 & 6,83 & 15 & Acceptable \\
\hline V6 & 6,35 & 1,63 & 6,83 & 4 & Unacceptable \\
\hline V7 & 27,21 & 1,28 & 18,39 & 7 & Acceptable \\
\hline V8 & 27,21 & 1,28 & 18,39 & 14 & Satisfactory \\
\hline V9 & 24,69 & 1,43 & 0,17 & 6 & Acceptable \\
\hline $\mathrm{V} 10$ & 24,69 & 1,43 & 0,17 & 12 & Satisfactory \\
\hline V11 & 42,85 & 1,19 & 2,80 & 6 & Acceptable \\
\hline V12 & 42,85 & 1,19 & 2,80 & 13 & Satisfactory \\
\hline V13 & 12,35 & 0,62 & 0,13 & 12 & Acceptable \\
\hline V14 & 12,35 & 0,62 & 0,13 & 4 & Unacceptable \\
\hline
\end{tabular}

Table 4 Criteria of interpretation of the wear value

\begin{tabular}{|c|c|c|}
\hline No. & $\begin{array}{c}\text { Value of wear } Z[\mathrm{~g}], \text { along the } \\
\text { friction path } l=20000 \mathrm{~m}, \text { at the } \\
\text { friction speed } v=2 \mathrm{~m} / \mathrm{s}\end{array}$ & $\begin{array}{c}\text { Evaluation } \\
\text { criterion }\end{array}$ \\
\hline 1 & $0 \div 0,2$ & Satisfactory \\
\hline 2 & $0,21 \div 0,4$ & Acceptable \\
\hline 3 & $Z>0,41$ & Unacceptable \\
\hline
\end{tabular}

The analysis was started with determination of canonical discriminant functions which separate the groups being considered. The functions may have any form but, in practice, linear functions are usually used. Therefore, they have the following form [16, 17]:

$D_{k j}=\beta_{0}+\beta_{1} x_{1 k j}+\ldots+\beta_{p} x_{p k j}$

where: $p$ - the number of discriminant variables $(p=4$ in the example), $n$ - sample size ( $n=15$ in the example), $g-$ number of groups ( $g=3$ in the example), $D_{k j}$ - value of the canonical discriminant function for the $k^{\text {th }}$ case in the $j^{\text {th }}$ group, $k=1, \ldots, n$ and $j=1, \ldots, g, x_{i k j}-$ value of the $i^{\text {th }}$ discriminant value for the $k^{\text {th }}$ case in the $j$-th group, $i=$ $1, \ldots, p, \beta_{i}$ - factors of the canonical discriminant function determined based on the function's properties.

The problem of determination of factors $\beta_{i}$ can be reduced to solving a matrix equation $[16,17]$ :

$(\boldsymbol{M}-\lambda \boldsymbol{W}) \boldsymbol{\beta}=0$,

where: $\boldsymbol{W}$ - intra-group matrix of mixed squares and mixed products, $\boldsymbol{M}$ - intergroup matrix of squares and mixed products, $\boldsymbol{\beta}$ - vector of factors of canonical discriminant functions, $\lambda$ - so called matrix own value. Tab. 5 shows the calculated, raw and standardised values of discriminant function factors. The calculations were done with the use of the STATISTICA software package, version 9.0. form:

Canonical discriminant functions have the following

$$
\begin{aligned}
& D_{1}=8,618-0,136(\mathrm{C}+\mathrm{Cr})-0,085 \mathrm{Mn}-0,011 \mathrm{Re}-0,590 \mathrm{H},(3) \\
& D_{2}=0,097+0,047(\mathrm{C}+\mathrm{Cr})+0,097 \mathrm{Mn}+0,036 \mathrm{Re}-0,156 \mathrm{H} .(4)
\end{aligned}
$$

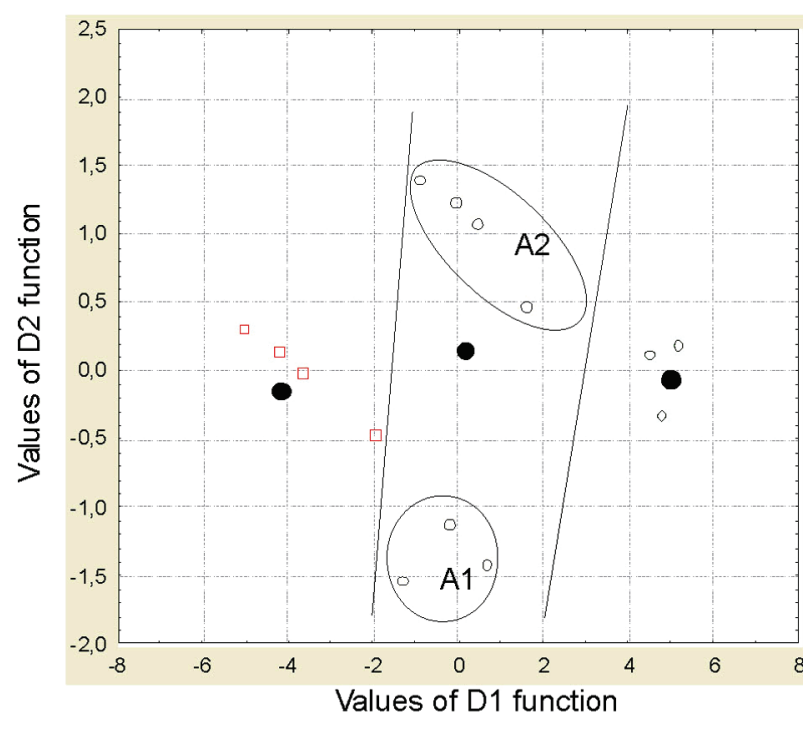

$\bigcirc$ Acceptable $\square$ Satisfactory $\diamond$ Unacceptable

Figure 2 The diagram of the canonical value distribution

The first function is responsible for $99 \%$ of the explained variance (the other one for only $1 \%$ ), this means that the first function is the most important. The conclusion was drawn on the basis of the values of discriminant function factors, which however have not been presented in the paper because of its limited volume. In order to determine the contribution of each discriminant function in discrimination group, one can use the diagram of the canonical value distribution (Fig. 2).

The results presented in Fig. 2 confirm the result of the explained variation. The diagram shows that the values of the material wear (satisfactory, acceptable and unacceptable) are discriminated by the first discriminant function (nearly vertical lines can be drawn which separate the groups $-99 \%$ of the explained variation). A very interesting case was observed in the acceptable wear group. There are two distinct sets $\mathrm{A} 1$ and $\mathrm{A} 2$. The first one includes construction material with small content of $\mathrm{C}+\mathrm{Cr}$, but with more advantageous soil conditions (higher humidity $\mathrm{H}$ ). The A2 set is associated with a material which is more resistant to wear, but which does not reach a satisfactory level of wear intensity due to the action of dry gravel. 
Another measure can also be employed in the multidimensional space of variables - Mahalanobis distance. It is a distance between each case and the group centroid. It is noteworthy that the smaller the Mahalanobis distance, the more one can be sure of belonging to the group. Fig. 3 shows a diagram of squares of Mahalanobis distances for the data being analysed.

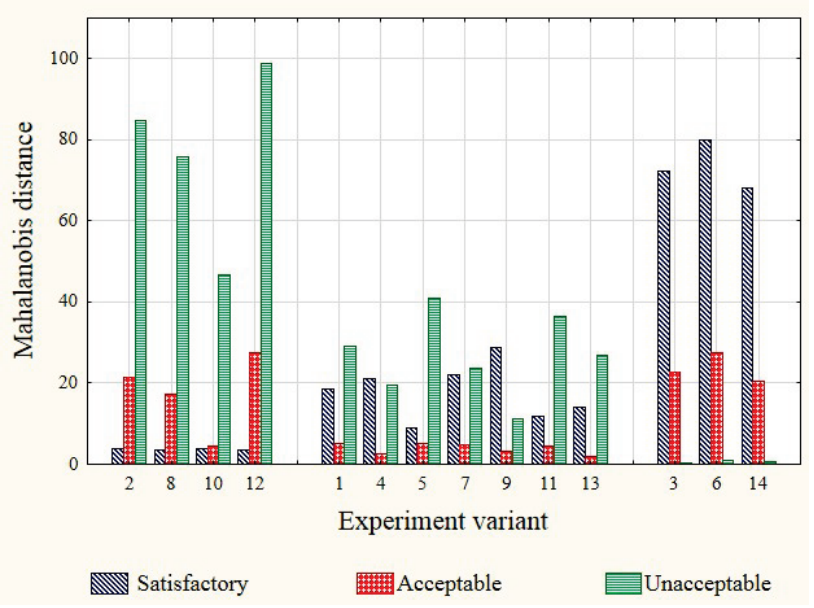

Figure 3 A bar chart of Mahalanobis distance

An analysis of Fig. 3 reveals that the functions discriminate the three groups of intensity of wear. The intensity of wear in the first four variants (V2, V8, V10, V12) was the lowest and the bars marked "satisfactory" were the smallest in those cases. The middle group comprises seven variants with the acceptable status, with the bars marked "accept" assuming the lowest values. The last group (V3, V6, V14) is also characterised by good discriminant properties - the "not-accept" bars are the smallest. Therefore, the wear intensity model for the working elements in gravel soil can be regarded as one that properly describes the effect of the construction material and soil humidity on the wear value.

\section{Simulation of material wear employing the discriminant model}

The model can simulate the changes of material wear value depending on the material chemical composition and the soil humidity. The simulation is made using the equations of the $D_{1}$ and $D_{2}$ functions (1). Three changes of positions of points on the diagram of the canonical values spread are given in order to picture the changes of wear intensity (Fig. 4). The simulation was made for variants V7, V10 and V14, changing the following properties in them, respectively: soil humidity from 4 to $12 \%, \mathrm{Mn}$ content from 1,4 to $0,6 \%$ and $\mathrm{C}+\mathrm{Cr}$ content from 12 to $35 \%$. The vectors drawn in Fig. 4 show the direction and value of the changes of estimated wear. Apparently, the change of wear intensity largely depends on soil humidity and on $\mathrm{C}+\mathrm{Cr}$ content. Changes of the content of $\mathrm{Mn}$ and other elements also affect wear intensity; however, the effect is not significant (e.g. vector starting from point V10).

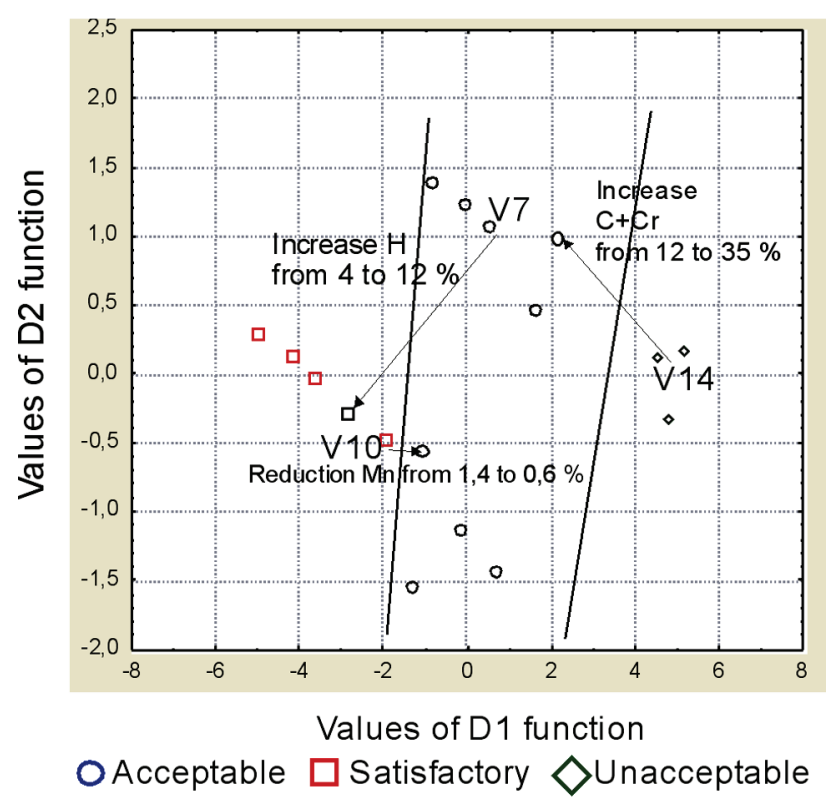

Figure 4 A diagram of canonical values spread with vectors of status change

\section{Conclusions}

Use of the discriminant analysis procedures makes possible to prove which factors essentially influence wear development of working elements used in abrasive soil pulp. Therefore, one can select a set of those factors, whose particular values do not give a clear-cut answer in aspect of the wear intensity and only their multidimensional analysis makes such a set useful while choosing a construction material. The built model can be used over the selection of construction materials for working elements using the wear resistance criterion. Simulation of the chemical composition change of the material and its influence on the qualitative wear interpretation is easy to realize. The determined discrimination functions let introduce different data combinations (elements percentage composition) and tracking of the change of location of the points on the canonical values scatter chart gives a clear view in the interpretation of the results of the implemented changes.

The worked out discriminant model and the contentrelated analysis of the composition of the investigated materials allows for formulation of the following detailed conclusions:

1) It is interesting that two sets emerged in the group of the wear intensity, evaluated as acceptable. The first one contains working parts made of a material containing over $20 \%$ of $\mathrm{C}+\mathrm{Cr}$, used in soil with the humidity level $\mathrm{H}$ of over $12 \%$. The second set contains parts with the $\mathrm{C}+\mathrm{Cr}$ content exceeding $25 \%$ which are used in dry gravel $(\mathrm{H}<6 \%)$. Therefore, the choice of working parts can be controlled, taking into account the technological and economic criterion.

2) The layer characterized with the lowest wear is the plasma arc build-up weld made with PMFe61P powder. The structure of that material consists of solid solution, $\left(\mathrm{Fe}, \mathrm{Cr}_{7} \mathrm{C}_{3}\right)$ primary carbide metalloaded with $\left[\alpha+(\mathrm{Fe}, \mathrm{Cr})_{7} \mathrm{C}_{3}\right]$ eutectic and borides and carbide borides type $\mathrm{FeB}, \mathrm{Cr}_{2} \mathrm{BC}$ and $\mathrm{M}_{23}(\mathrm{C}, \mathrm{B})_{6}$. 
3) Next material, characterized with the lowest wear, is build-up weld made with the ENSW2MoB electrode. The structure of that material is similar to the previous one, except that instead of borides and carbide borides there are present molybdenum carbide $\left(\mathrm{Mo}_{2} \mathrm{C}\right)$, tungsten carbide (VC), titanium carbide (TiC). Hardness of the mentioned above carbides is adequately equal to: 2000,2800 and 3200 HV.

4) The chemical composition influences the most the structure and properties of the build-up welds. High $\mathrm{C}$ and $\mathrm{Cr}$ content and additives like $\mathrm{B}, \mathrm{V}, \mathrm{Mo}, \mathrm{Ti}$ and $\mathrm{Nb}$ contribute to the creation of the structures with the increased resistance to wear in abrasive soil pulp, particularly the dry one. The EStelMn60 build-up weld is characterized by the high Mn content. The $\mathrm{C}$ content $(3,4 \%), \mathrm{Cr}$ content $(31,6 \%)$ and $\mathrm{Mn}$ content $(4,32 \%)$ cause creation of the structure containing, besides the primary carbides, retained austenite. Manganese does not create special carbides in weld material. Its basic task is to increase the amount of austenite. The weld material containing the retained austenite is characterized by the increased wear resistance in soil, which is particularly significant during simple wear processes. The phenomenon is explained by transformation of austenite into martensite in micro-volumes under abrasive loads. It is necessary to admit that the mentioned above buildup welds are characterized by the diverse structure, beginning with dendritic, through tabular and finishing with batten one.

One worked out models for the other sorts of soil (silty and clayey), which have not been described in this paper due to its limited volume. The models for the other sorts of soil (silty and clay) have not been described in this paper due to its limited volume. The models also respond well to the change of the chemical composition of the material and humidity of the soil. In further papers related to the multi-dimensional analysis of construction materials wear modelling the plan is to use the cluster and correspondence analyses. First attempts of application of those mathematical tools brought very promising effects.

\section{References}

[1] Owsiak, Z. Wear of symmetrical wedge-shaped tillage tools. // Soil Tillage Research. 43, 3-4 (1997), pp. 295-308. DOI: 10.1016/S0167-1987(97)00020-2

[2] Quirke, S.; Scheffler, O.; Allen, C. An Evaluation of the Wear Behaviour of Metallic Materials Subjected to Soil Abrasion. // Soil Tillage Research. 11 (1988), pp. 27-42. DOI: 10.1016/0167-1987(88)90029-3

[3] Khruschiov, M. M.; Babiczev, M. A. Abrasive Wear. Nauka Moscou 1970.

[4] Napiórkowski J. Zużyciowe oddziaływanie gleby na elementy robocze narzędzi rolniczych. // Inżynieria Rolnicza, 12 (2005), pp. 127-133.

[5] Stachowiak, G. W.; Betchelor, A. W. // Engineering Tribology. Elsevier BH 2005.

[6] Tong, J.; Wang, H.; Ma, Y.; Ren, L. Two-Body Abrasive Wear of the Outside Shell Surfaces of Mollusc Lamprotula fibrosa Heude, Rapana venosa Valenciennes and Dosinia anus Philippi. // Tribology Letters. 19, 4 (2005), pp. 331338. DOI: $10.1007 / \mathrm{s} 11249-005-7450-8$

[7] Napiórkowski, J. Analiza właściwości glebowej masy ściernej w aspekcie oddziaływania zużyciowego. // Tribologia. 5 (2010), pp. 53-62.

[8] Napiórkowski, J.; Pękalska, L.; Pękalski, G. Structure of material and its wear resistance in the soil. // Tribologia. 6 (1998), pp. 871-879.

[9] Rutkowski, P.; Stobierski, L. Microstructure evolution of composite materials based on transition metal carbides. // Ceramic Materials. 61 (2) (2009), pp. 140-145.

[10] Er, U.; Par, B. Wear of plowshare components in SAE 950C steel surface hardened by powder boriding. // Wear. 261 (2006), pp. 251-255. DOI: 10.1016/j.wear.2005.10.003

[11] Horvat, Z.; Filipovic, D.; Kosutic, S.; Emert, R. Reduction of moldboard plough share wear by combination technique of hard facing. // Tribology International. 41 (2008), pp. 778-782. DOI: 10.1016/j.triboint.2008.01.008

[12] Natsis, A.; Petropoulos, G.; Piandazaras, C. Influence of local soil conditions on moldboard ploughshare abrasive wear. // Tribology International. 41 (2008), pp. 151-157. DOI: 10.1016/j.triboint.2007.06.002

[13] Maruda, R.; Feldshtein, E.; Legutko, S.; Królczyk, G. Research on emulsion mist generation in the conditions of Minimum Quantity Cooling Lubrication (MQCL). // Tehnicki Vjesnik-Technical Gazette. 22, (2015), pp. 12131218. DOI: 10.17559/TV-20140423221850

[14] Maruda, R.; Krolczyk, G.; Michalski, M.; Nieslony, P.; Wojciechowski, S. Structural and microhardness changes after turning of the AISI 1045 steel for Minimum Quantity Cooling Lubrication. // Journal of Materials Engineering and Performance. (2016). DOI: 10.1007/s11665-016-2450-4

[15] Twardowski, P.; Legutko, S.; Krolczyk, G.M.; Hloch, S. Investigation of wear and tool life of coated carbide and cubic boron nitride cutting tools in high speed milling. // Advances in Mechanical Engineering. 7, 6 (2015), pp. 1-9. DOI: $10.1177 / 1687814015590216$

[16] Klecka, W. R. Discriminant analysis. Sage, London 1980. DOI: $10.4135 / 9781412983938$

[17] Stanisz, A. Przystępny kurs statystyki z zastosowaniem STATISTICA PL. Tom 3. Analizy wielowymiarowe. StatSof Kraków 2007.

\section{Authors' addresses}

Jerzy Napiorkowski, Prof. DSc. PhD. Eng.

Pawel Mikolajczak, PhD. Eng.

University of Warmia and Mazury,

Department of Vehicle and Machine Construction and Operation 11 Oczapowskiego street, 10-719 Olsztyn, Poland

E-mails: napj@uwm.edu.pl; pawel.mikolajczak@uwm.edu.pl

Stanislaw Legutko, Prof. DSc. PhD. Eng., Prof. h. c.

Faculty of Mechanical Engineering and Management Poznan University of Technology

3 Piotrowo street, 60-965 Poznan, Poland

E-mail: stanislaw.legutko@put.poznan.pl

Jolanta B. Krolczyk, Prof. DSc. PhD. Eng.

Faculty of Mechanical Engineering

Opole University of Technology

5 Mikolajczyka street, 45-271 Opole, Poland

E-mail: j.krolczyk@po.opole.pl 